\title{
ROBORIC KITS IN SECONDARY SCHOOL
}

\section{Michaela VESELOVSKÁ - Karolína MAYEROVÁ}

\begin{abstract}
In the article we introduce robotic kits (RK) which are used at secondary schools. We provide overview of RK based on different criteria. We select two most suitable RK and we are going to use them in classes where we are conducting our research. We also provide a description of the tested activities with RK. In conclusion, we provide results of our qualitative research. Based upon results, we choose one RK to continue with in further research.
\end{abstract}

Key words: educational robotics, robotic kits, secondary school.

\section{ROBOTICKÉ STAVEBNICE NA 2. STUPNI ZŠ}

Abstrakt: V článku sa venujeme robotickým stavebniciam (RS) používaným na druhom stupni základných škôl. Poskytujeme prehl'ad RS podl'a rôznych kritérií. Z nich vyberáme dve najvhodnejšie RS do tried, kde prebieha náš výskum. V článku sa nachádza i popis otestovaných aktivít $\mathrm{s}$ dvomi vybranými RS. V závere článku uvádzame výsledky realizovaného kvalitatívneho výskumu, podl’a ktorého vyberáme jednu RS, pomocou ktorej bude pokračovat' d’alší výskum.

Kličcová slova: edukačná robotika, RS, druhý stupeň základnej školy.

\section{1 Úvod}

$\mathrm{Na}$ Slovensku je od roku 2008 povinná informatická výchova už od druhého ročníka 1. stupňa ZŠ, ktorá umožňuje konceptuálne vzdelávanie študentov v oblasti digitálnej gramotnosti (ŠVP, 2011). Súčast'ou tohto predmetu je i oblast' robotiky či ovládania RS, ktorých využívanie vo vyučovacom procese sa odporúča $\mathrm{i} \mathrm{v}$ štátnom vzdelávacom programe (ŠVP, 2011). Ako jeden z prvých krokov pri vyučovaní s RS, ktoré musí učitel' urobit', je výber RS. V tomto článku predstavujeme čast' nášho výskumu, ktorý pojednáva práve o výbere vhodnej RS pre druhý stupeň ZS̆. Poskytujeme stručný prehl'ad RS, ktoré sú dostupné na trhu a ktoré sú podl'a nás vhodné pre túto vekovú kategóriu. Prehl'ad týchto RS je podávaný $\mathrm{z}$ viacerých uhlov pohladu podl'a rôznych kritérií, ktoré sledujú ciele výučby.

\section{Použité výskumné metódy \\ Teoretické východiská}

Záujem o využívanie RS v procese učenia a učenia sa neustále stúpa. Aktivity s RS so sebou prinášajú i potenciál pre rozvoj procesu učenia sa (Papert, 2003). Využit' robotiku vo vyučovaní však nie je jednoduché. Dôležité je uvedomit' si, že technológia sama o sebe neprináša signifikantný výsledok v rozvoji žiadaných zručností a schopností, ktoré by mali nadobúdat' žiaci počas štúdia na základnej škole. Okrem technológií je potrebný i vhodný študijný plán, metodický materiál a vyučovacie metódy (Projekt Infovek, 2005). Podl'a Cvika (2005) sa začleňovanie edukačnej robotiky do vyučovacieho procesu na Slovensku stáva realitou. Práca $\mathrm{s}$ RS dokáže v značnej miere podporovat' rozvoj medzipredmetových vzt'ahov. $\mathrm{Z}$ doterajších výskumov vyplýva, že výskumníci spájajú robotiku (stavebnice LEGO a systém GIS) a vytvárajú aktivity na prepojenie robotiky hlavne sprírodovednými predmetmi ako matematika, fyzika (Williams a kol. (2007), Nugent a kol. (2008), Mitnik a kol (2008), Nugent a kol. (2009)). Barreto (2011) tvrdí, že 80 percent preštudovaných štúdií súvisiacich s vyučovaním robotiky sa zameriava hlavne na témy z oblasti fyziky a matematiky. Iní výskumníci a učitelia - napr. Resnick (1991) - sa snažia motivovat' i študentov, ktorí sa zaujímajú o umenie. Spojenie robotiky s výtvarnou výchovou a hudobnou výchovou môže zatraktívnit' edukačnú robotiku aj pre dievčatá a deti, ktoré sa nezaujímajú o prírodné vedy. Práve za týmto účelom bola vytvorená RS PicoCricket (The Playful Invention Company, 2006), ktorá sa žial' prestala vyrábat'.

V našom výskume by sme chceli pracovat' $\mathrm{s}$ RS, ktorá žiakom umožní rozvoj ich umeleckej stránky a zvýši motiváciu pri učení sa u humanitne a spoločensky orientovaných žiakov.

Naším ciel'om je vybrat' RS, ktorá by bola menej náročná na stavbu a programovanie. 
Týmto spôsobom by sme chceli vytvorit' priestor pre spojenie edukačnej robotiky s výtvarnou výchovou a so slovenským jazykom.

\section{Výskumné metódy}

Realizovali sme pilotnú štúdiu, ktorá sa stala úvodom do hlbšieho výskumu realizovaného $\mathrm{v}$ rámci dizertačnej práce.

V úvode sme sa rozhodli realizovat' teoretický výskum zameraný na prieskum existujúcich RS. $\mathrm{Na}$ jeho základe sme vytvorili prehl'ad RS a kritéria pre výber RS podl'a daného edukačného ciel'a.

$\mathrm{Na}$ základe kritérií sme vybrali dve najvyhovujúcejšie RS pre náš nasledujúci výskum: LEGO Mindstorms NXT a LEGO WeDo. Pričom sme sa rozhodli LEGO WeDo skombinovat' nielen s WeDo Software, ale aj s programovacím prostredím Scratch. Naše rozhodnutie vyplývalo $\mathrm{z}$ charakteru vybranej výskumnej vzorky (piaty ročník základnej školy), na ktorej chceme realizovat' aj náš dizertačný výskum.

Ďalej sme viedli kvalitatívny výskum s použitím nasledujúcich metód: zúčastnené pozorovanie, fotografie, video, analýza produktov, interview s učitel'mi (Švaříček, 2007). Tieto dáta sme analyzovali a dospeli k záverom, ktoré uvádzame v závere článku.

\section{Priebeh a výsledky výskumu}

Realizovaná pilotná štúdia, ako sme spomínali, je rozdelená na dve časti (teoretický výskum a kvalitatívny výskum).

V prvej časti výskumu sme robili teoretický prieskum existujúcich RS vhodných na využitie vo výučbe alebo pri vol'nočasových aktivitách. Našli sme sedemnást' RS, roztriedili sme ich podl'a určitých spoločných znakov a zaznamenali do tabul'ky.

V Tabul'ke 1 sa nachádzajú RS, pri ktorých je uvedený ich názov, cena, odporúčaná veková kategória a možnost' konštrukcie a programovania $(\mathrm{P})$. V časti Odporúčaná veková kategória sme uviedli vek, ktorý udali jednotlivé spoločnosti poskytujúcich možnosti zakúpenia RS na svojich webových stránkach. Možnost' konštrukcie RS sme rozdelili na technickú $(\mathrm{T})$ a dizajnovú (D) čast'. Technická čast' v rámci použitia všetkých dielov RS dovol'uje postavit' len určitý počet robotických modelov. Do dizajnovej časti patria RS, s ktorá umožňuje postavit' vlastné originálne modely. Možnost' programovania uvádzame, ak k danej RS existuje programovacie prostredie. Možnost' konštrukcie a programovania s danou stavebnicou je označená „х“ vtedy, ak stavebnica takúto možnost' neponúka a , $\sqrt{ }$ “, ak takúto možnost' ponúka. Tabul'ka je navyše rozdelená do piatich častí a to na Iba konštrukčné RS, Iba programovatel'né RS, Pohyby kociek, Dosky a Kombinované (umožňujú konštrukciu aj programovanie a nepatria medzi Pohyby kociek alebo Dosky).

\begin{tabular}{|c|c|c|c|c|c|}
\hline \multicolumn{6}{|c|}{ Prehl'ad RS } \\
\hline \multirow[t]{2}{*}{ Názov } & \multirow{2}{*}{ Cena } & \multirow[t]{2}{*}{ Vek } & \multicolumn{2}{|c|}{$\mathbf{K}$} & \multirow[t]{2}{*}{$\mathbf{P}$} \\
\hline & & & $\mathbf{T}$ & $\mathbf{D}$ & \\
\hline \multicolumn{6}{|c|}{ Iba konštrukčné } \\
\hline Engino & $\$ 79,95$ & Od $6 \mathrm{r}$. & $\checkmark$ & $x$ & $x$ \\
\hline Merkur & Od $70,75 €$ & Od $7 \mathrm{r}$. & $\checkmark$ & $\checkmark$ & $x$ \\
\hline \multicolumn{6}{|c|}{ Iba programovatel'né RS } \\
\hline mOway & $\$ 199$ & Od 12 r. & $x$ & $x$ & $\checkmark$ \\
\hline Papero & Prototyp & Od $7 \mathrm{r}$. & $x$ & $x$ & $\checkmark$ \\
\hline Scribler & $\$ 139,99$ & Od $14 \mathrm{r}$. & $x$ & $x$ & $\checkmark$ \\
\hline \multicolumn{6}{|c|}{ Pohyby kociek } \\
\hline Cubelets & $\$ 160$ & Od $8 \mathrm{r}$ & $x$ & $\checkmark$ & $\checkmark$ \\
\hline Topobo & $\begin{array}{l}\$ 149- \\
\$ 225\end{array}$ & $5-13 \mathrm{r}$. & $x$ & $\sqrt{ }$ & $x$ \\
\hline \multicolumn{6}{|c|}{ Dosky } \\
\hline Arduino & Od 79,90€ & Od 14 r. & $\checkmark$ & $x$ & $\checkmark$ \\
\hline $\begin{array}{c}\text { BoeBot } \\
\text { Robot }\end{array}$ & $\$ 159,99$ & Od $14 \mathrm{r}$. & $x$ & $x$ & $\checkmark$ \\
\hline $\begin{array}{c}\text { Boffin } \\
750\end{array}$ & $77 €$ & Od 8 r. & $\checkmark$ & $\checkmark$ & $\checkmark$ \\
\hline $\begin{array}{l}\text { GoGo } \\
\text { Board }\end{array}$ & $\$ 105,08$ & Od $14 \mathrm{r}$. & $\checkmark$ & $\checkmark$ & $\checkmark$ \\
\hline $\mathrm{kVex}$ & $300-500 €$ & Od 14 r. & $\checkmark$ & $x$ & $\checkmark$ \\
\hline \multicolumn{6}{|c|}{ Kombinované } \\
\hline $\begin{array}{l}\text { Fischer } \\
\text { Technic }\end{array}$ & $69,95 €$ & Od $7 \mathrm{r}$. & $\checkmark$ & $x$ & $\checkmark$ \\
\hline $\begin{array}{c}\text { LEGO } \\
\text { Mindstor } \\
\text { ms RCX }\end{array}$ & $\begin{array}{c}\text { Staršia } \\
\text { verzia NXT }\end{array}$ & Od 8 r. & $\checkmark$ & $\checkmark$ & $\checkmark$ \\
\hline $\begin{array}{c}\text { LEGO } \\
\text { Mindstor } \\
\text { ms NXT }\end{array}$ & $352,51 €$ & Od 8 r. & $\checkmark$ & $\checkmark$ & $\checkmark$ \\
\hline $\begin{array}{l}\text { LEGO } \\
\text { WeDo } \\
\end{array}$ & $133,29 €$ & Od $7 \mathrm{r}$. & $\checkmark$ & $\sqrt{ }$ & $\checkmark$ \\
\hline OLLO & $\begin{array}{l}\$ 20- \\
\$ 1200\end{array}$ & Od $7 \mathrm{r}$. & $\checkmark$ & $x$ & $\checkmark$ \\
\hline
\end{tabular}

Tabul'ka 1: Prehl'ad robotických stavebnic.

Na niektorých základných školách a stredných školách na Slovensku sa vo výučbe používa stavebnica LEGO Mindstorms NXT, LEGO Mindstorms RCX (Cvik, 2005).

Pri vol'be správnej RS je dôležité brat' do úvahy viacero faktorov a vzhl'adom na to sme 
vytvorili niekol'ko kritérií (faktorov), ktoré by mohli vyučujúcim takúto vol'bu ul'ahčit'.

\section{Kritériá výberu vhodnej RS}

Jedným z prvých faktorov ovplyvňujúcich výber RS a jej zaradenie do výučby je vzdelávací ciel' - v akom rozsahu by sme chceli danú RS vo výučbe využit' (v zmysle dizajnovania, konštruovania a programovania robotického modelu). Ďalším faktorom je i skutočnost' či $\mathrm{k}$ určitej RS existuje relevantné metodické zabezpečenie. Vyučujúci by mal pri výbere taktiež uvažovat' nad primeranost'ou danej RS $\mathrm{k}$ veku žiakov (kognitívne štádium vývinu) aj nad jej zrozumitel'nost'ou. Tu sa vynárajú rôzne otázky (vzhl'adom na zvolený vzdelávací ciel') ohl'adom typu programovacieho prostredia k zvolenej RS (ikonografické, či je v materinskom jazyku, ...). Prepojenie s robotickými sút'ažami i potenciál pre rozvoj medzipredmetových vzt'ahov zohráva tiež istú (motivačnú) úlohu i z pohl'adu učitel'a. Ďalším významným kritériom je cena (súvisiaca aj s počtom zakúpených $\mathrm{RS}$ - pokial' je potrebných viac RS môže vzniknút' tendencia prikláňania sa k RS s nižšou cenou) a servis $\mathrm{k}$ vybranej RS. Tu treba zohl'adňovat' i kvalitu, možnost' výmeny či dokúpenia jednotlivých dielov RS. Pričom pri atraktívnej RS popri požiadavke dostupnosti stavebnice pre školu môže vzniknút' i požiadavka dostupnosti stavebnice pre rodičov, teda pre domáce použitie. Po prehodnotení všetkých doterajších kritérií alebo faktorov je potrebné získat' predovšetkým ústretovost' komunity, teda nájst' podporu u zriad'ovatel'a, vedenia, kolegov, žiakov aj rodičov.

Dané RS sme zvolili tak, aby $\mathrm{z}$ hl'adiska vzdelávacieho ciel'a dovol'ovali prácu na dizajne, konštrukcií i programovaní robotického modelu z výberu sme vylúčili Iba konštrukčné RS, Iba programovatel'né RS a Pohyby kociek. RS zaradené vo vyššie uvedenej tabul'ke ako Dosky síce splńajú podmienku konštrukcie a programovania modelu, avšak nespĺn̆ajú požiadavky zhl'adiska nášho ciel'a, ktoré uvádzame v nasledujúcej kapitole. Do užšieho výberu sa dostali Kombinované RS. Tu sme brali do úvahy najskôr dostupnost' RS. Na trhu (CVIK, 2012) sú dostupné RS LEGO Mindstorms NXT a LEGO WeDo pre školy i pre rodičov. V konečnom dôsledku sme porovnávali cenu (NXT majú značne vyššiu cenu - vid' tabul'ku), primeranost' (WeDo spĺnajú menšiu náročnost' konštrukcie a programovania), metodické zabezpečenie, prepojenie s robotickými sút'ažami (NXT - FIRST LEGO League) i potenciál pre rozvoj medzipredmetových vzt'ahov a obe RS spĺn̆ali tieto kritériá $\mathrm{v}$ závere takmer podobne preto sme vybrali obe RS, ktoré sme následne využili v druhej časti výskumu.

\section{Testovanie rôznych typov úvodných aktivít s rôznymi RS}

V druhej časti výskumu sme realizovali kvalitatívny výskum.

Vybrali sme tri paralelné triedy piateho ročníka na základnej škole v Stupave. V prvej triede bolo sedem dievčat a sedem chlapcov, $\mathrm{v}$ druhej triede bolo šest' dievčat a sedem chlapcov a v tretej triede bolo šest' dievčat a pät' chlapcov. Výber tried považujeme za vhodný kvôli možnosti vytvorenia skupín pozostávajúcich iba $\mathrm{z}$ dievčat, iba $\mathrm{z}$ chlapcov alebo kombinovane - aj $\mathrm{z}$ chlapcov aj $\mathrm{z}$ dievčat. Vo všetkých skupinách sa súčasne nachádzali dvaja výskumníci, ktorí celý priebeh hodín fotografovali, nahrávali video záznamy, prípadne jeden z výskumníkov písal terénne zápisky. Ďalší $\mathrm{z}$ výskumníkov dané hodiny i viedol.

Vytvorili sme tri typy úvodných aktivít na prácu s RS k prvým dvom vyučovacím hodinám (jedna vyučovacia hodina trvá 45 minút). Tieto aktivity z hl'adiska nášho ciel'a mali splńat' požiadavky:

\section{- Konštruktivistický}

a konštrukcionistický prístup.

- Oboznámenie a ujasnenie si pojmu „robot"“.

- Nižšia náročnost' z hl'adiska dizajnovania, stavby a programovania RS.

Spomínané požiadavky sme stanovili aj kvôli tomu, aby sa žiaci mohli zamerat' aj na umeleckú stránku robotického modelu - na vytvorenie príbehu, $\mathrm{v}$ ktorom by bol tento robotický model zakomponovaný ako napríklad v robotickom modeli „Plt'ka“ (Veselovská, 2012), robotickom modely „Mačka“ a „Torta“ (MIT Media Lab, 2007).

\section{RS LEGO Mindstorms NXT}

Prvý typ dvoch úvodných hodín (v jednom týždni prebiehala jedna vyučovacia hodina) je zameraný na prácu s RS LEGO Mindstorms NXT.

Prvú polovicu prvej hodiny sme zahájili podobne ako odporúča (Gura, 2011) úvodným riadeným rozhovorom so žiakmi o pojme „robot“. V druhej polovici sa žiaci rozdelili do štyroch skupín (pretože si to vyžadoval obmedzený počet robotov). Každý robot bol postavený v základnom stave (typ konštrukcie 
modelu s pripojenými senzormi, ktorého postup stavby je súčast'ou súpravy $\mathrm{k}$ RS) a obsahoval v sebe niekol'ko (štyri alebo viac) typov programov, ktoré riadili jeho správane. Úlohou žiakov bolo zistit' správanie robota po spustení programu a následne ho vysvetlit' vyučujúcemu. Žiaci mali objavovat' ako fungujú jednotlivé senzory pripevnené na robota (zvukový, tlakový, ultrazvukový a svetelný senzor).

Druhá vyučovacia hodina bola zameraná na typ programovania NXT kocky v priamom režime - priamo pomocou tlačidiel na NXT kocke (nie pomocou softvéru k danej RS v počítači). Priamy režim obsahuje dve sady základných príkazov na ovládanie pohybu robota a ovládanie jednotlivých senzorov. Počas tejto hodiny boli žiaci rozdelení znova do rovnakých skupín ako na predchádzajúcej vyučovacej hodine. $\mathrm{V}$ úvode tejto aktivity jeden z výskumníkov (zároveň i vyučujúci) názorne vysvetlil žiakom programovanie v priamom režime na jednom robotovi, pričom žiaci programovali paralelne s jeho vysvetl'ovaním. Vysvetlený program potom spoločne každá skupina a aj vyučujúci vyskúšali. Úlohou žiakov bolo naprogramovat' správanie robota podla svojich vlastných predstáv, pričom v závere hodiny svojho robota mala každá skupina prezentovat'. Teda daného robota pomenovat', vysvetlit' jeho správanie a to následne demonštrovat' spustením programu $\mathrm{v}$ priamom režime.

\section{RS LEGO WeDo}

Druhý typ úvodných dvoch hodín sa zameriava na prácu s RS LEGO WeDo spolu s originálnym programovacím prostredím $\mathrm{k}$ tejto stavebnici.

Prvá hodina bola venovaná ujasňovaniu si pojmu „,robot". Žiaci sa najskôr rozdelili do piatich skupín (podl'a počtu RS). Každá skupina mala za úlohu napísat' na papier (jedna skupina písala na jeden papier) všetky pojmy, ktoré si spájajú s pojmom „,robot". Ked’že niektorí žiaci sa dožadovali možnosti na papier aj kreslit', neskôr popri písaní kreslila na papier každá skupina (analýza vzniknutých prác bude predmetom d'alšieho výskumu). V druhej polovici hodiny sme viedli so žiakmi rozhovor a kreslili popri tom na tabul'u pojmovú mapu na základe žiackych výpovedí. V závere hodiny sa žiaci ešte pät' minút zoznamovali s jednotlivými dielmi RS.

Počas druhej vyučovacej hodiny mali žiaci za úlohu postavit' l'ubovol'ný robotický model a v závere hodiny ho prezentovat' spolužiakom (mali uviest' meno robota, vysvetlit' jeho správanie a demonštrovat' program). V úvode hodiny jeden výskumník vysvetlil žiakom základné informácie ohl'adom stavby a programovania RS WeDo (v priebehu piatich minút). Žiaci ihned' začali pracovat' so stavebnicou i s programovacím prostredím.

\section{RS LEGO WeDo + Scratch}

Tretí typ úvodných dvoch hodín spája výučbu s RS s prácou v prostredí Scratch.

Úloha úvodnej hodiny bola rovnaká ako $\mathrm{v}$ predchádzajúcich dvoch triedach, teda zoznámit' a ujasnit' si pojem ,,robot“. Žiaci sa $\mathrm{v}$ úvode rozdelili do skupín podl'a počtu RS. Každá skupina mala za úlohu napísat' na papier (jedna skupina mala k dispozícií jeden papier) rôzne pojmy k pojmu, ,robot“. Po pätnástich minútach jeden výskumník ukázal žiakom krátke video, v ktorom boli ukázané rôzne typy existujúcich aj vymyslených robotov. Potom mali žiaci ešte niekol'ko minút' na dopisovanie papierov. V poslednej tretine hodiny sme viedli so žiakmi rozhovor, ktorého úlohou bolo vytvorenie definície k pojmu ,robot“".

Druhá vyučovacia hodina mala rovnaké zadanie ako v predchádzajúcej triede, ktorá pracovala tiež s RS LEGO WeDo. Avšak úvod hodiny začal navyše i vysvetlením základných prvkov na ovládanie motora $\mathrm{v}$ programovacom prostredí Scratch.

\section{Analýza dát}

Pri práci s RS LEGO Mindstroms NXT boli žiaci rozdelení do dvoch trojčlenných (tri dievčatá a traja chlapci) a dvoch štvorčlenných skupín (štyri dievčatá a štyria chlapci). Počas prvej hodiny vykazovali žiaci vysoké očakávania od správania robotického modelu (chlapec: „,Robot spraví, čo mu poviem. “). Pokial' sa robot nesprával podl'a predpokladu žiakov, napríklad nereagoval na zvuk alebo na prekážku, reakcie žiakov vyzerali: „Čo si hluchý? Čo si slepý?". Až neskôr žiaci zistili, že robot nemusí reagovat' na všetky senzory, ktoré sú súčast'ou jeho konštrukcie. Pri programovaní správania robota počas druhej vyučovacej hodiny s RS pracovalo menej ako polovica žiakov (v každej skupine jeden až dvaja žiaci). Pri práci s RS sa zriedkavo striedali iný členovia skupiny. Takmer v polovici prípadov žiaci nepochopili typ a funkciu senzorov. Napríklad v trojčlennej skupine skladajúcej sa iba $\mathrm{z}$ dievčat, nevedeli vysvetlit', ktoré senzory si vybrali a snažili sa reagovat' takmer na všetky senzory (tlieskali, stláčali tlakový senzor, zakrývali ultrasonický senzor). Tiež takmer v polovici prípadov sa objavil 
problém s pochopením príkazov a ich postupností. Napríklad pri prezentácií správania robota $\mathrm{v}$ závere vyučovacej hodiny $\mathrm{v}$ dvoch skupinách prezentujúci vysvetl'ovali celkovo odlišné správanie robota ako to, ktoré robot predviedol (napríklad robot reagoval na iné senzory a iným spôsobom ako uviedli žiaci).

Do aktivít s LEGO WeDo s originálnym softvérom sa zapájali skoro všetci žiaci okrem jedného chlapca $z$ trojčlennej skupiny pozostávajúcej iba z chlapcov. Žiakom nebolo potrebné dôkladne vysvetl'ovat' programovanie v originálnom softvéri, už pri prvom kontakte intuitívne skúšali a vedeli popísat' funkciu jednotlivých ikoniek na prácu s motorom. Žiaci aktívne tvorili a rekonštruovali svoje robotické modely viac krát pričom v závere hodiny mali dostatočný priestor (10 minút), aby svoju prácu prezentovali. Pri prezentácií žiaci zaujímavo porozprávali charakteristiky svojich modelov. Napríklad vysvetl'ovali jeho funkciu a možné využitie v súčasnosti aj v budúcnosti.

Pri práci s LEGO WeDo v spojení so Scratchom pracovali takmer všetci žiaci okrem jedného dievčat'a $z$ trojčlennej skupiny (dve dievčatá a jeden chlapec). Skupina pozostávajúca z dvoch chlapcov postavila model, kde zapojila oba senzory z RS k počítaču a v programovacom prostredí sa vyskytla chyba. Pretože nechcel pracovat' sobidvoma senzormi súčasne a nepretržite vydával pískajúci zvuk. Žiakom sme na konci prvej hodiny vysvetl'ovali základné príkazy na prácu s motorom a tiež aj v priebehu celej druhej hodiny (individuálne každej skupine). Žiakov zaujal kocúr na obrazovke a chvíl'ami skúmali i časti programovacieho prostredia. Ked'že sa s týmto prostredím žiaci ešte nestretli, nové a nepreskúmané prostredie dávalo žiakom možnost' odpútavania pozornosti od konkrétnej úlohy, ktorej sa mali venovat' (stavba a programovanie robotického modelu).

\section{Odôvodnenie výberu RS}

Rozhodli sme sa pre RS LEGO WeDo s originálnym softvérom k tejto RS (WeDo Software). Naše rozhodnutie bolo podporené i reakciami pani učitel'ky (informatiky), ktorá bola prítomná na všetkých šiestich hodinách. Použitie zvolenej RS umožňovalo žiakom venovat' sa v prevažnej väčšine času hlavne dizajnu a stavbe robotického modelu. Ponúkal sa im priestor taktiež pre plánovanie stavby, úvahy o mene robota (ktoré väčšina žiakov vymyslela až pri poslednom dotváraní robota) a mnohé skupiny dokonca svojho robota viackrát rozobrali a postavili odznova. Žiaci takúto zásadnu zmenu stavby robili často a počas jednej vyučovacej hodiny zmenili model aj trikrát. Ked’že žiaci mali dostatok času na viacnásobnú zmenu stavby robota, domnievame sa, že je možné spojit' prácu s vybranou RS aj s inými činnost'ami, ktoré spomína Gura (2011) ako je napríklad cielené plánovanie stavby robota (zapisovanie plánu do denníka), dokumentovanie postupu plánu stavby a dizajnu robota a taktiež i programovanie robota. Pričom samotný robot bude súčast'ou väčšej témy, ktorú si žiaci zvolia z ponuky poskytnutej učitel'om, ako to ukazuje i Resnick a kol. v (MIT Media Lab, 2007). Takýmto spôsobom by sme chceli spojit' s edukačnú robotiku s výtvarnou výchovou a slovenským jazykom.

Kombinácia LEGO WeDo s jazykom Scratch by bola prijatel'ná v prípade, ak vyučujúci už pred tým pracoval so žiakmi v tomto prostredí. Scratch je možné použit' i pri úvodných hodinách s LEGO WeDo. Avšak na základe analýzy dát sme zistili, že pri zložitejších konštrukciách dochádza kobmedzeniu funkčnosti niektorých častí stavebnice.

$\mathrm{Na}$ základe analýzy nami odučených hodín a rozhovorov s viacerými učitel'mi, ktorí pracujú so žiakmi s RS LEGO Mindstorms NXT sme dospeli knasledujúcim záverom. Danú stavebnicu odporúčame vtedy, ak vyučujúci môže venovat' robotike viacero vyučovacích hodín (viac ako 10 hodín). Pretože, ak by učitel' chcel so žiakmi riešit' nie celkom triviálne úlohy a žiaci by mali stavat' vlastné robotické modely, musia sa najskôr zoznámit' s jednotlivými dielmi RS a získat' určité skúsenosti s ich stavbou (napr. tieto skúsenosti získajú po určitom počte postavených modelov podl'a návodu, ....). Taktiež oboznámenie sa s programovacím prostredím pre RS LEGO Mindstorms NXT si vyžaduje dlhší čas. Počas realizovaných hodín žiaci programovali iba $\mathrm{v}$ priamom režime a napriek tomu sme u žiakov pozorovali nepremyslené pokusy o vytvorenie programu. Napríklad sme pozorovali, že približne každý druhý pokus o program nebol vytvorený premyslene - žiaci síce program vytvorili, ale nevedeli ako funguje a pri jeho prezentovaní nedokázali zdôvodnit' správanie robota. Preto si myslíme, že pre žiakov je prínosnejšie vytvárat' a skúmat' programy (programy $\quad \mathrm{v}$ priamom režime aj v programovacom prostredí) v priebehu dlhšieho časového rozpätia ako je jedna vyučovacia hodina. Teda v celkovom dôsledku je potrebné vyčlenit' na prácu s touto RS väčší počet vyučovacích hodín (viac ako 10). 


\section{Diskusia a závery}

V článku sme poskytli prehl'ad RS, ktoré sú vhodné na prácu na druhom stupni ZŠ. Vytvorili sme zoznam kritérií ovplyvňujúce výber vhodnej RS do výučby na základnej škole. Na základe týchto kritérií sme si zvolili dve vhodné RS (LEGO Mindstorms NXT a LEGO WeDo). Jednu RS (LEGO WeDo) sme skombinovali s programovacím prostredím Scratch. K týmto RS sme navrhli tri rozdielne typy úvodných aktivít. Každý typ aktivít bol otestovaný v priebehu dvoch vyučovacích hodín. Na základe analýzy aktivít, analýzy rozhovorov s učitel'mi a ciel’a nášho dizertačného výskumu sme vybrali stavebnicu LEGO WeDo, s ktorou chceme pokračovat' $v$ nasledujúcom výskume. Budúci výskum bude obsahovat' d'alší prieskum, postupnú analýzu a vytvoríme taktiež sadu medzipredmetových aktivít zameraných na spojenie RS s výtvarnou výchovou a slovenským jazykom.

\section{Literatura}

[1] BENITTI, F. (2011). Exploring the educational potential of robotics in schools: A systematic review. In Computers \& Education 58 (2012) 978-988

[2] CVIK, P. 2005. Uplatňovanie učebnej pomôcky ROBOLAB v základných školách na Slovensku - výsledky výskumu. In MIF 26. ISSN 1335-7794, 2005, roč. 14, s. 143.

[3] CVIK, P. 2012. EDUXE Distribútor učebných pomôcok. LEGO Education. [online]. Aktualizované 2012. Dostupné na internete:

< http://www.eduxe.sk/les/>.

[4] GURA, M. 2011. Getting Started with LEGO Robotics. In: ISTE, 2011. ISBN 978-1-56484298-5.

[5] MIT Media Lab. 2007. New Pathways into Robotics: Strategies for Broadening

Participation. [online]. 2007. Aktualizované jún 2007. Dostupné na

internete:

$<$ http://web.media.mit.edu/ mres/papers/NewPat hwaysRoboticsLLK.pdf>.

[6] MITNIK, R., NUSSBAUM, M., SOTO, A. (2008). An autonomous educational mobile robot mediator. Autonomous Robots, 25(4), 367-382.

[7] NUGENT, G., BARKER, B., GRANDGENETT, N. (2008). The effect of 4-H robotics and geospatial technologies on science, technology, engineering, and mathematics learning and attitudes. In J. Luca, E. Weippl (Eds.), Proceedings of world conference on educational multimedia, hypermedia and telecommunications (pp. 447-452). Chesapeake, VA: AACE.

[8] NUGENT, G., BARKER, B., GRANDGENETT, N., ADAMCHUK, V. (2009). The use of digital manipulatives in $k$-12: robotics, GPS/GIS and programming. In Frontiers in education conference, 2009. FIE '09. 39th IEEE (pp. 1-6, 18-21).

[9] PAPERT, S. (1993). Mindstorms: Children, computers, and powerful ideas (2nd ed.). New York, NY: Basic Books.

[10] Projekt Infovek. 2005. Infovek: LEGO. [online]. 2005. Aktualizované 2006-12-12. Dostupné na internete: $<\mathrm{http}: / /$ lego.infovek.sk/>. [11] RESNICK, M. (1991). Xylophones, hamsters, and fireworks: the role of diversity in constructionist activities. In I. Harel, \& S. Papert (Eds.), Constructionism. Norwood, NJ: Ablex Publishing Corporation.

[12] Štátny pedagogický ústav. 2011. Štátny vzdelávaci program. [online]. Bratislava:

ŠPÚ v Bratislave, 2011. Aktualizované 2011. Dostupné na internete: <http://www.statpedu.sk/sk/Statny-vzdelavaciprogram.alej>.

[13] ŠVA ̌́ÍČEK, R - ŠEĎOVÁ, K a kol. 2007. Kvalitativní výzkum v pedagogických vedách.

Praha: Portál, s. r. o., 2007.

[14] The Playful Invention Company. 2006. PicoCricket: Invention kit that integrates art and technology. [online]. 2006. Aktualizované marec 2009. Dostupné na internete: <http://picocricket.com>.

[15] VESELOVSKÁ, M. 2012. Spolupráca detí $v$ tímoch na robotických sútažiach. [online]. Bratislava, 2012. Aktualizované 2011. Dostupné na internete:

<http://www.miska.own.sk/prace.html>.

[16] WILLIAMS, D., MA, Y., PREJEAN, L., LAI, G., Ford, M. (2007). Acquisition of physics content knowledge and scientific inquiry skills in a robotics summer camp. Journal of Research on Technology in Education, 40(2), 201-216.
Mgr. Michaela Veselovská,
Mgr. Karolína Mayerová
Katedra základov a vyučovania informatiky Fakulta matematiky, fyziky a informatiky UK Mlynská dolina
842 48, Bratislava, $S R$
E-mail: veselovska@fmph.uniba.sk
mayerova@fmph.uniba.sk
Www pracovisko:
http://www.edi.fmph.uniba.s 